\title{
Molestia de Raynaud de origem paludica
}

\author{
Pelo Dr. Aristides G. Guimarães, Pre= \\ parador de Parasitologia.
}

A epidemia de paludismo, nestes ultimos annos, nos tem dado margem a observar fórmas clinicas as mais variadas possiveis.

o exame systematico de sangue, para a pesquisa de hematozoarios, tem sido de grande utilidade para o diagnostico, por causa, principalmente, do tratamento especifico (quinino, azul de methyleno, 914, etc. etc.).

Observámos, no mez de julho de 1915, na terceira enfermaria de clinica medica da Santa Casa, actualmente sob a direç̧ão do Prof. Dr. Ovidio Pires de Campos, um doente procedente de Baurú, em pleno accesso pernicioso, cujo exame de sangue nos mostrou numerosos anneis da tropical.

Infelizmente, não pudemos assistir ao começo do syndrome observado, por estar em $2 .^{\circ}$ periodo a doença de Raynaud.

Eis um resumo da observação: - L. T., syrio, de 20 annos de idade, solteiro, trabalhador, procedente de Baurú. Doenças anteriores - não menciona. Apanhou paludismo em Baurú, ha um mez; tem febre todos os dias. $O$ doente estava em estado sub-comatoso, febril, de modo a não se queixar de dores nos artelhos de ambos os pés. Lingua saburrosa, figado dolorido á palpação e augmentado de volume -2 dedos abaixo do rebordo costal. o baço augmentado 3 dedos abaixo do rebordo costal e doloroso á pressão. Nada mais de importante havia nos outros orgams. $O$ exame de sangue revelou numerosos anneis da tropical. Fizemos uma injecção de 914 e o doente melhorou consideravelmente, sahindo do estado sub-comatoso em 
que se achava. Passados alguns dias, foi que, com as dores, verificámos que o doente apresentava os artelhos com uma coloração violacea. Apresentava tambem phlyctenas que se rompiam. A gangrena continuou a seguir sua marcha ascendente e tomou os terços inferiores das duas pernas.

O que nos levou a descrever esta observação é a coincidencia da doença de Raynaud ou, melhor, do syndrome, com o paludismo, facto já vereficado por muitos autores. Ora o syndrome desapparece com o áccesso, ora persiste depois da cura e toma uma fórma mais grave como aconteceu com o doente da observação presente. Estas gangrenas podem ser secundarias ou paludicas propriamente ditas.

A etiologia da doença de Raynaud é muito variada (palutismo, lepra, diabetes, tuberculose, estado tetanico do grande sympathico, etc. etc.) Eis uma estatistica.sobre a etiologia da molestia de Raynaud, organizada por Castellino e Cardi (1895) :

Syphilis, 22. - Paludismo, 19. - Tuberculose, 14. - Alcoolismo e arterio-esclerose, 16. - Diabetes, 23. - F. typhoide, 3. - Pneumonia, 2. - Leucemia, 8. - Anemia perniciosa, 9. - Nephrite, 6. - Cardiopathias, 10. - Rheumatismo, 5: Nevroses, 171. - Total: 310.

Homens, 87. - Mulheres, 229.

André Leger apresenta, no quinto volume de pathologia exotica (anno 1912), um caso de doença de Raynaud, em pleno paludismo, mas regressando com a medicação quininica. E' verdade que a doença estava em sèu primeiro periodo e, na nossa observação, estava em plena gangrena. Outro facto interessante foi a eosinophilia local, o que não observámos no nosso doente, apesar de havermos feito varios esfregaços dos pontos gangrenados e proximidades, nos periodos de crise e fóra delle.

André Leger verificou tamben que a eosinophilia desapparecia com a gangrena, gradativamente.

(Continúa). 


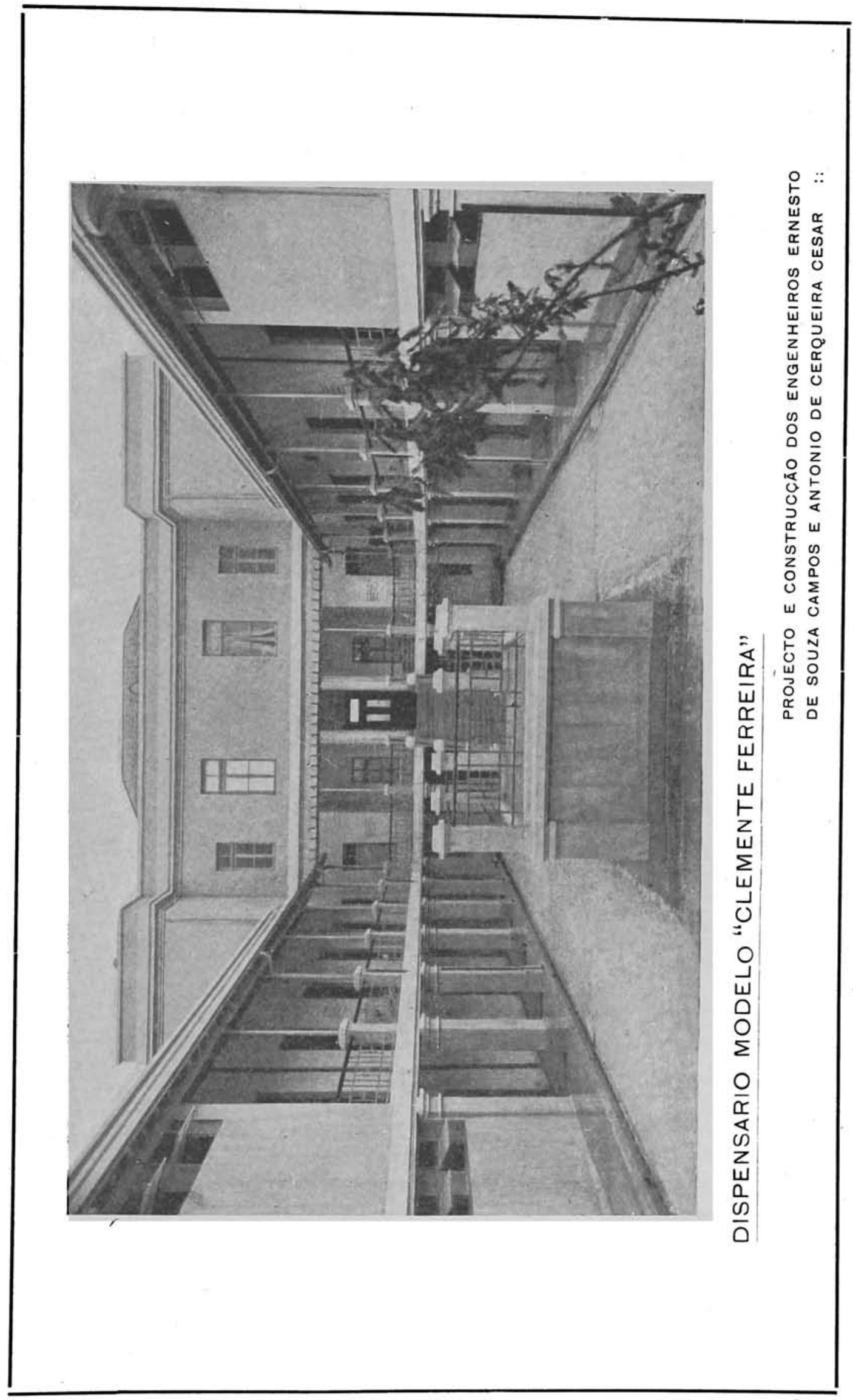

